Health policy

\section{Commissioning from specialist children's trusts}

\section{T Hutchison}

\section{The Children's Trust initiative is a freedom not a solution}

A lan Milburn, the Government Health Secretary, threw the phrase "children's trusts" into the arena of public debate when he addressed a national social services conference in Cardiff on 16 October 2002. He said:

"I intend to create specialist children's trusts to jointly plan, commission, finance, and, where it makes sense, deliver children's services. Children's trusts which commission services will be based in local councils with the power for the first time to commission health as well as social care.

And for those children's trusts that want to specialise in providing services we will want to explore a range of models in different parts of the country. These could potentially include local not for profit public interest companies that could enlist the involvement of the community, voluntary, and private sectors alongside the public sector.

We want to pilot this new approach, so in December this year my department and the education department will ask for expressions of interest from local organisations keen to test how children's trusts could improve local services." 12

\section{WHICH CHILDREN'S SERVICES?}

Paediatricians reading this will be well aware of the problems in acute services that are being addressed by the National Service Framework and other initiatives. The children's trust proposals are not principally about acute services. Rather they encompass:

- Services for disabled children

- Children with special educational needs

- Child protection

- Identification, referral, and tracking of children at risk

- Speech and language therapy
- Child and adolescent mental health services

- Areas where social care, health, and education services need to work together.

\section{WHAT'S WRONG WITH THESE SERVICES?}

A recent government spending review looked at the services for children at risk.

- It identified a lack of unified local authority vision.

- There was no coordination in the way new initiatives were used.

- There was insufficient local ownership of services and an imbalance between prevention and crisis intervention.

- Parents have to negotiate bureaucratic boundaries between services that are supposed to work together to help their children.

- Rigid ways of working by these service providers stifle creativity and innovation.

- There are huge problems in recruiting and retaining a skilled and motivated work force.

\section{AN EXAMPLE: PROVISION AND MAINTENANCE OF EQUIPMENT FOR DISABLED CHILDREN}

This is now funded from numerous different budgets across health, education, social services, the voluntary sector, and parents themselves. Generally any professional that recommends equipment has access to a budget. Each budget has a life of its own, often being a part of some larger managed budget which may include adult provision. Rules about what can and can't be done are everywhere. Often these are to ration the budget.

- Only two pairs of boots a year.

- Only one powered chair (you can't have one at home and school without it travelling every day).

- We won't repair anything we have not supplied.

- That piece of equipment is new (or expensive) and we have no budget to supply it.
- And most wastefully, no way of recycling equipment which is perfectly safe but a child no longer uses. There are stories of expensive unused standing frames in school cupboards.

As a result there is waste, interagency haggling, and from the parent perspective, time delay and labyrinthine bureaucratic structure to cope with.

\section{IMPROVING THE SERVICE FOR CHILDREN IN NEED}

In an attempt to make services more child focused and coordinated across social services, health education, housing, and other agencies at a local level, the government cross cutting review that informed the spending review recommended three directions for improvement:

(1) Early identification of need to ensure preventive services are available before the moment of crisis.

(2) Better focus of mainstream and children's services to ensure they respond better to those most in need.

(3) Strengthen existing local partnerships and pilot new children's trust models for integrated services.

\section{LOCAL PARTNERSHIPS}

In many parts of the country there are joint commissioning committees. They usually work around individual cases where very expensive and extraordinary services are needed. For example:

- Supporting technology dependent children in the community.

- Youngsters with learning difficulties and medical conditions needing 52 week placement away from home.

There are local experiments with single points of referral for children in need, and care pathways for specific circumstances.

\section{POSSIBLE STRUCTURE OF CHILDREN'S TRUSTS}

Unlike adult care trusts where health agencies take the lead, children's trusts will be based within one local authority or cover several local authorities. Neither are they actually legal trusts in the way we understand health trusts. The word trust is misleading and the search is on for a better title. There is no centrally determined structure for the new organisation. The purpose of pilots is to test different arrangements. However the government has proposed three models.

(1) The board of the children's trust is a subcommittee of the local council executive.

(2) There is no board as such; the children's trust is an ad hoc committee made up of the chief officers from different services who agree to act jointly, sharing elements of control over their respective service to pursue joint commissioning goals. 
(3) The children's trust is based outside the local authority in a company. The local authority would do the commissioning but the company would provide the service; and there is already legislation allowing local authorities to work in this way.

\section{LINKS WITH PREVENTIVE STRATEGIES}

Government is asking all local authorities to develop interagency coordinated strategies to prevent children at risk developing problems. This is independent of children's trusts but about building on good practice. However, one of the aims of children's trusts is to break down the barriers between agencies, so it will be interesting to see if the pilot districts perform well when it comes to preventive strategies.

\section{WHY SHOULD LOCAL AUTHORITIES TAKE PART IN THESE PILOTS?}

The main incentive is to provide better children's services. Expected benefits include:

- Development of integrated pathways of care.

- Better information transfer between agencies. Wouldn't it be wonderful if all new IT systems in a locality were commissioned to be compatible?

- Combined and coordinated assessment processes rather than multiple individual agency exercises.

- More flexibility of staff working between different sectors with more integrated training and more diverse career development possibilities.

- Better leadership, management, accountability, and long term planning.

The government plans to set up a unit between the Department of Health and the Department for Education and Skills to support development of the pilot sites and share information between them.

\section{PILOT SITES SELECTED}

One third of English local authorities expressed an interest in becoming a pilot site. On 10 July 2003; the Children's Minister, Margaret Hodge, announced the names of 35 selected "children trust pathfinders". They will receive funding for three years to establish themselves and the government has promised to evaluate their success.

The chosen authorities are Barnsley, Bolton, Brighton and Hove, Devon, East Yorkshire, Gateshead, Greenwich, Hammersmith and Fulham, Hampshire, Newcastle, North Lincolnshire, Redbridge, Sutton, Trafford, Bexley, Blackburn with Darwen, Calderdale, Croydon, Essex, Hertfordshire, Leicester, Nottinghamshire, Sandwell, Sheffield, Solihull,
South Tyneside, Telford and Wrekin, Tower Hamlets, West Sussex, Wokingham, Cambridgeshire, City of York, Darlington, Ealing, and Portsmouth.

\section{PERSONAL VIEW}

My immediate reaction on hearing the children's trust announcement was. "Oh no, I have been in a primary care trust barely a year and another reorganisation looms." Having read the background for this article, I now feel that it is not a threat but an opportunity. It is refreshing to see new initiatives being developed through pilot projects. Such a change from the central imposition of inflexible and badly developed service change. However, the pilot sites will have to grapple with many difficulties.

\section{COMMISSIONING}

Perhaps I hoped for too much from a process that promised proactive service planning by the people with the resources. All around me the efforts of the commissioners seem disappointingly feeble. All the Primary Care Trust commissioners get is the privilege of struggling to manage huge budget deficits run up by long established monopoly health service providers. They cannot control the providers because the money they pay them is in huge blocks, rarely earmarked for individual services. It is very hard to disinvest in a particular service when no one can tell you how much it costs and when the staff and facilities are also part of other services at the same time.

Pressure on the providers comes from many directions other than the commissioners:

- Government targets for waiting lists

- Government quality inspections

- Local political pressure

- Relationships with universities and Royal Colleges

- Legislation, such as the European Working Time Directive

- Professional pride and ambition.

The problems of commissioning within the health service are great. The challenge of unified commissioning across old agency boundaries is going to be greater. There will be set up costs for the new system. I would expect the costs of this change within a failing local authority to be very much higher. I see no reason to think that efficiencies gained will release more money than the new process costs. Being a commissioner with a budget deficit leaves little room for manoeuvre.

On the other hand, local commissioning as a part of the structure of the NHS is relatively new. Despite the fact that we are not very good at it, I can imagine no alternative way to improve children's services. We have to refine our commissioning techniques and be patient. It could take years to get results. ${ }^{3}$

COMBINED PAEDIATRIC SERVICES

Children's health services were commissioned and provided by the local authority long before the NHS was established. Medical officers were officers of local government from 1910 until 1974. Since then there has been a steady amalgamation of the community and hospital streams of provision. In some parts of the country the two budgets are still separately identifiable. In others there is a combined acute and community district provision. The College of Paediatrics and Child Health proposes a future where community and general paediatrics are one and the same thing, with the training to match. It would indeed be a shame if the formation of children's trusts had the effect of widening a gap between acute and community paediatricians. However, I can also argue that identifiable services for children in need are vulnerable in combined trusts, where in direct competition with, for example, neonatal staffing or orthopaedic waiting list initiatives. This comes down to whether commissioning of children's services can ever have real teeth.

\section{ACTIVITY DATA}

Health service trusts have never collected good data on what community services are actually provided. Acute trust activity analysis stops after counting numbers of new and review outpatient appointments along with outpatient waiting times. Perhaps one positive thing the pilot districts could do is try and measure the health component effectively. I don't see how it can be commissioned or evaluated if it cannot be quantified. This sort of development can hardly be cost neutral.

\section{GOVERNANCE}

For professionals working across previous boundaries there will have to be new methods of accountability. The governance arrangements for the pilot sites will have to depend on how the sites are set up. I cannot imagine that modern governance requirements would ever allow the transfer of clinicians' employment to a local authority.

\section{AFTER THE PILOTS}

There are no overt financial incentives for local authority piloting. Those with good leadership, well developed interagency cooperation, and co-terminus geography will be the likely chosen applicants. If the pilots are successful we cannot assume that the new structures will be transferable to struggling or failing local authorities without considerable modification. 


\section{FAMILIES WANT BETTER OUTCOMES}

There are many ways of improving services without altering existing structure: investment in leadership and joint training; cooperative interagency projects, care pathways, and tuning in to families' experience of the service they receive. Structural change is no substitute for these quality measures. At the same time we need the freedom to change structure when we have done the other things. I see the children's trust initiative not as a solution but as a freedom: available to health education and local authorities when the time and local circumstances are right.

Arch Dis Child 2003;88:745-747

Correspondence to: Dr T Hutchison, Child Health Department, Bath NHS House, Newbridge Hill, Bath BA1 3RF, UK; tom.hutchison@banes-pct.nhs.uk

\section{REFERENCES}

1 Department of Health. www.doh.gov.uk/ childrenstrusts/stakeholders.htm

2 Department of Health. Time to break up old monolithic social services, 16 Oct 2002. Department of Health Press release, 2002/ 0432.

3 ADSS. Tomorrow's children. A discussion paper on UK child care services in the coming decade, September 2002, Association of Directors of Social Services, ADSS office, 020 87418147.

IMAGES IN PAEDIATRICS.

Allergic contact dermatitis to henna tattoo

$\mathrm{T}$

his 9 year old boy had a henna tattoo of a Chinese dragon painted on his back while abroad on holiday. The tattoo colour faded over the subsequent week but the area became acutely erythematous, swollen, and blistered, and was painful and pruritic. Examination revealed an erythematous weepy dermatitis in the shape of a dragon on the boy's back with surrounding eczematous changes. He had had a henna tattoo the previous year with no ill effects.

Traditional henna is a naturally occurring brown dye made from the leaves of the tree Lawsonia inermis. Henna is applied to the skin in a design and allowed to dry, and is later washed off. The longer the contact time with the skin the darker the resulting colour. Henna tattoos can be further darkened by the addition of an artificial dye, paraphenyldiamine (PPD), a major constituent fo permanent hair dye. This additive makes the tattoo quicker and easier to apply. Our patient was positive on patch testing to PPD and it was presumed that primary sensitisation occurred with his first uneventful henna tattoo the previous year. Re-exposure to PPD caused a type IV hypersensitivity (delayed) reaction resulting in the allergic contact dermatitis and secondary eczematous changes. Holiday henna tattoos are becoming increasingly fashionable, so parents shold be warned that the darker paints often contain PPD, a potent contact allergen.

S Baron, K Baxter, M Wilkinson Dermatology Department, The General Infirmary at Leeds, Great George Street, Leeds LSI 3EX, UK

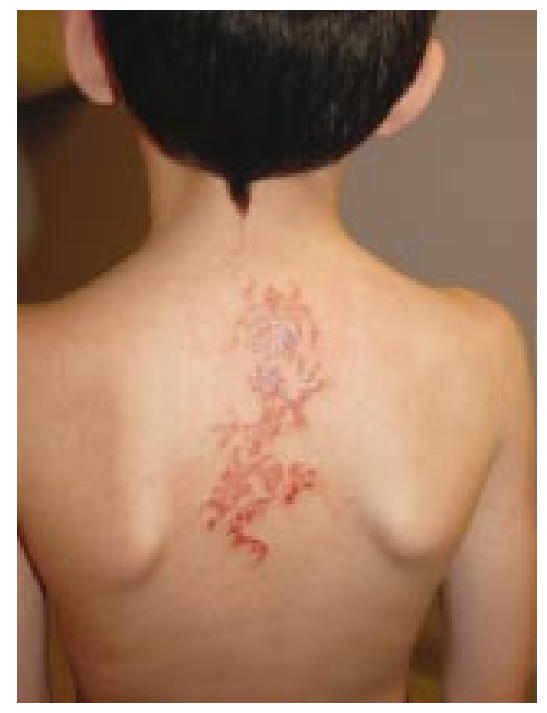
zannerzu@aol.com 